\title{
Centric Fusions behind the Karyotype Evolution of Neotropical Nannostomus Pencilfishes (Characiforme, Lebiasinidae): First Insights from a Molecular Cytogenetic Perspective
}

\author{
Alexandr Sember ${ }^{1}$, Ezequiel Aguiar de Oliveira ${ }^{2,3}{ }^{\circledR}$, Petr Ráb ${ }^{1}$, Luiz Antonio Carlos Bertollo ${ }^{2}$, \\ Natália Lourenço de Freitas ${ }^{2}$, Patrik Ferreira Viana ${ }^{4}$, Cassia Fernanda Yano ${ }^{2}$, \\ Terumi Hatanaka ${ }^{2}$, Manoela Maria Ferreira Marinho ${ }^{5}$, Renata Luiza Rosa de Moraes ${ }^{2}$ (D), \\ Eliana Feldberg ${ }^{4}$ (D) and Marcelo de Bello Cioffi ${ }^{2, *}$ \\ 1 Laboratory of Fish Genetics, Institute of Animal Physiology and Genetics, Czech Academy of Sciences, \\ Rumburská 89, 27721 Liběchov, Czech Republic; sember@iapg.cas.cz (A.S.); rab@iapg.cas.cz (P.R.) \\ 2 Departamento de Genética e Evolução, Universidade Federal de São Carlos, São Carlos, São Paulo 13565-905, \\ Brazil; ezekbio@gmail.com (E.A.d.O.); bertollo@ufscar.br (L.A.C.B.); lfreitasnatalia@gmail.com (N.L.d.F.); \\ yanocassia@gmail.com (C.F.Y.); hterumi@yahoo.com.br (T.H.); rlrdm@hotmail.com (R.L.R.d.M.) \\ 3 Secretaria de Estado de Educação de Mato Grosso-SEDUC-MT, Cuiabá 78049-909, Brazil \\ 4 Instituto Nacional de Pesquisas da Amazônia, Coordenação de Biodiversidade, Av. André Araújo 2936, \\ Petrópolis, Manaus 69067-375, Brazil; patrik.biologia@gmail.com (P.F.V.); feldberg@inpa.gov.br (E.F.) \\ 5 Universidade Federal da Paraíba (UFPB), Departamento de Sistemática e Ecologia (DSE), Laboratório de \\ Sistemática e Morfologia de Peixes, João Pessoa 58051-090, Brazil; manoela.marinho@gmail.com \\ * Correspondence: mbcioffi@ufscar.br; Tel.: +55-16-3351-8431; Fax: +55-16-3351-8377
}

Received: 9 December 2019; Accepted: 8 January 2020; Published: 13 January 2020

\begin{abstract}
Lebiasinidae is a Neotropical freshwater family widely distributed throughout South and Central America. Due to their often very small body size, Lebiasinidae species are cytogenetically challenging and hence largely underexplored. However, the available but limited karyotype data already suggested a high interspecific variability in the diploid chromosome number $(2 n)$, which is pronounced in the speciose genus Nannostomus, a popular taxon in ornamental fish trade due to its remarkable body coloration. Aiming to more deeply examine the karyotype diversification in Nannostomus, we combined conventional cytogenetics (Giemsa-staining and C-banding) with the chromosomal mapping of tandemly repeated $5 \mathrm{~S}$ and $18 \mathrm{~S}$ rDNA clusters and with interspecific comparative genomic hybridization (CGH) to investigate genomes of four representative Nannostomus species: N. beckfordi, N. eques, N. marginatus, and N. unifasciatus. Our data showed a remarkable variability in $2 n$, ranging from $2 n=22$ in N. unifasciatus (karyotype composed exclusively of metacentrics/submetacentrics) to $2 n=44$ in $N$. beckfordi (karyotype composed entirely of acrocentrics). On the other hand, patterns of $18 \mathrm{~S}$ and $5 \mathrm{~S}$ rDNA distribution in the analyzed karyotypes remained rather conservative, with only two $18 \mathrm{~S}$ and two to four $5 \mathrm{~S}$ rDNA sites. In view of the mostly unchanged number of chromosome arms $(\mathrm{FN}=44)$ in all but one species (N. eques; $\mathrm{FN}=36)$, and with respect to the current phylogenetic hypothesis, we propose Robertsonian translocations to be a significant contributor to the karyotype differentiation in (at least herein studied) Nannostomus species. Interspecific comparative genome hybridization (CGH) using whole genomic DNAs mapped against the chromosome background of $N$. beckfordi found a moderate divergence in the repetitive DNA content among the species' genomes. Collectively, our data suggest that the karyotype differentiation in Nannostomus has been largely driven by major structural rearrangements, accompanied by only low to moderate dynamics of repetitive DNA at the sub-chromosomal level. Possible mechanisms and factors behind the elevated tolerance to such a rate of karyotype change in Nannostomus are discussed.
\end{abstract}


Keywords: comparative genomic hybridization; karyotype variability; repetitive DNAs; Robertsonian translocation

\section{Introduction}

The Neotropical region harbors the richest freshwater ichthyofauna in the world, with approximately 5200 species belonging to 17 orders, thus representing about $40 \%$ of the freshwater biodiversity worldwide [1-3]. Moreover, the amount of cryptic and until now morphologically undistinguishable species suggests much higher species diversity (e.g., [4-9]). Fueled by these discoveries, the knowledge about the karyotype differentiation in Neotropical fishes has been rapidly growing (especially during the last few decades) and several important models for studying both sympatric and allopatric speciation, species complexes, and sex chromosome evolution have emerged [9-11]. As a prominent example, a remarkable cytogenetic variability has been found in the Erythrinidae family (Characiformes) and especially in Erythrinus erythrinus and Hoplias malabaricus, where several cases of multiple karyotype forms per species, high dynamics of repetitive DNA distribution, and intriguing diversity of chromosomal sex determination have been reported [10,12].

The family Lebiasinidae, which contains at least 72 valid species widely distributed throughout Central and South America, is divided into two subfamilies: The Lebiasininae (genera Lebiasina, Piabucina, and Derhamia) and the Pyrrhulininae (Pyrrhulina, Nannostomus, Copeina, and Copella) [13]. The latter represents the most diverse clade and it is also characterized by an extreme reduction of body size in some of its representatives. The most speciose genera in the subfamily are Nannostomus and Pyrrhulina, as each of them involves 19 species. Members of the genus Nannostomus, commonly referred to as pencilfishes, inhabit typically the flooded forests of the Amazon basin and they are valuable for the aquarist pet trade due to their colorful pigmentation. However, from the taxonomic viewpoint, it is one of the most challenging Lebiasinidae genera; therefore, a suite of complementary methodologies, such as cytogenetic comparisons and molecular analyses, including recently applied DNA barcoding, are highly valuable for clarifying this issue $([14,15]$ and references therein).

The small size of most Lebiasinidae fishes (i.e., ranging from 16 to $70 \mathrm{~mm}$ in length) makes the cytogenetic investigations of this group challenging and labor intensive, which may explain the large gaps in their cytogenetic data [16-18]. Nevertheless, a steadily growing body of information on karyotype characteristics in Lebiasinidae has been generated within recent years, using both conventional and molecular cytogenetic techniques, bringing new important pieces into the puzzle of lebiasinid karyotype differentiation and its underlying evolutionary mechanisms. More specifically, high rate of repetitive DNA dynamics and the occasional emergence of neo-sex chromosomes were found among four Pyrrhulina taxa; one of them may represent a new, yet undescribed species $[19,20]$. Furthermore, contrasting patterns of repetitive DNA content and distribution as well as a putative nascent sex chromosome system were also reported for Lebiasina species, supporting at the same time relationships between the Lebiasinidae and Ctenoluciidae families [21]. In addition, the first molecular cytogenetic report on Copeina species is filling another gap in this research [22]. Hence, for comparative purposes, similar data are necessary to be gathered in the remaining four lebiasinid genera (i.e., in Copella, Derhamia, Piabucina, and Nannostomus). A proper comparative cytogenetic survey might further contribute to cytotaxonomic comparisons between Lebiasinidae and evolutionarily related lineages.

In contrast to relative stability of the $2 n$ in Copeina, Lebiasina and Pyrrhulina species karyotyped to date [16-22], representatives of Copella and Nannostomus display remarkable karyotype variability $[16,18]$. Indeed, even from limited karyotype data, it can be inferred that Nannostomus exhibits a wide range of $2 n$, from 22 (in N. unifasciatus) to 46 (in N. trifasciatus) $[16,18,23]$, suggesting an important role of Robertsonian rearrangements in its karyotype differentiation.

The aim of the present study was to provide the first finer-scale cytogenetic investigation in the genus Nannostomus, performed both by conventional (Giemsa staining and C-banding) and molecular 
(fluorescence in situ hybridization (FISH) with $5 \mathrm{~S}$ and $18 \mathrm{~S}$ rDNA probes and comparative genomic hybridization (CGH)) methods in four species, namely N. beckfordi, N. eques, N. marginatus, and N. unifasciatus.

\section{Materials and Methods}

\subsection{Sampling}

The collection sites, numbers, and sex of the individuals investigated are presented in Figure 1 and Table 1. All the specimens were collected under the appropriate authorization of the Brazilian environmental agency ICMBIO/SISBIO (License number 48628-2) and SISGEN (A96FF09). The specimens were taxonomically identified and sexed based on morphological characters and they were deposited in the fish collection site of the Museu de Zoologia da Universidade de São Paulo (MZUSP) under the voucher numbers 123071, 123079, 123083, and 123084. The experiments followed ethical and anesthesia conducts, in accordance with the Ethics Committee on Animal Experimentation of the Universidade Federal de São Carlos (Process number CEUA 1853260315) (Figure 1).

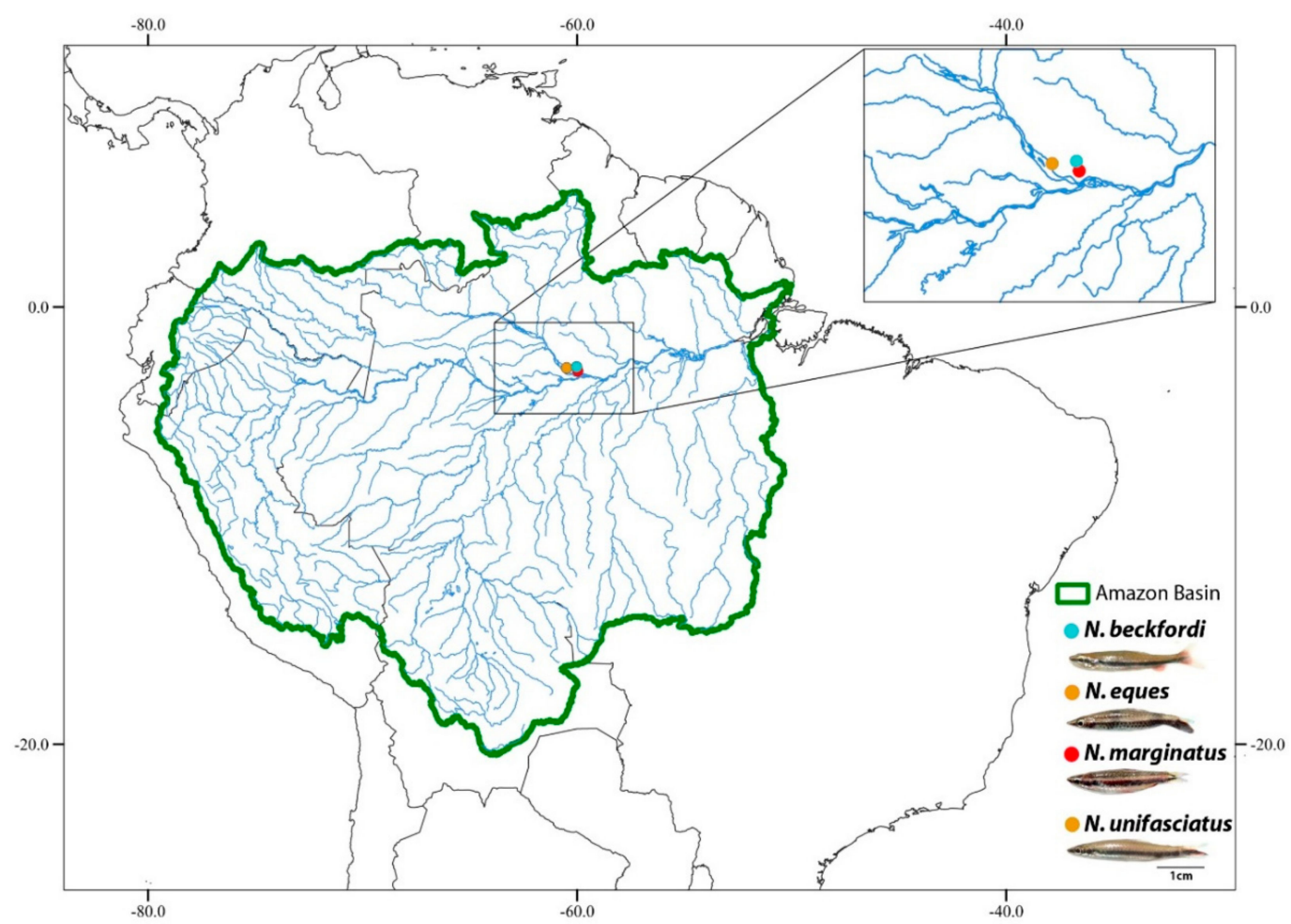

Figure 1. The map of Brazil with highlighted collection sites of Nannostomus beckfordi (blue circle), N. eques, N. unifasciatus (orange circle), and N. marginatus (red circle). The map was created using the following softwares: QGis 3.4.3, Inkscape 0.92, and Photoshop 7.0.

Table 1. Collection sites, $2 n$ and the sample sizes $(\mathrm{N})$ of the investigated Nannostomus species.

\begin{tabular}{|c|c|c|c|}
\hline Species & $2 n$ & Sampling Site & $\mathbf{N}$ \\
\hline Nannostomus beckfordi & 44 & $\begin{array}{c}\text { Agenor Stream } \\
\text { (Amazon River), AM }\end{array}$ & $(09$ 우 17 \\
\hline Nannostomus eques & 36 & Cuieiras River, AM & $\left(15+12 \sigma^{\top}\right)$ \\
\hline Nannostomus marginatus & 42 & $\begin{array}{l}\text { Adolpho Ducke reserve } \\
\text { (Negro River), AM }\end{array}$ & $\left(08\right.$ 우 $\left.12 \sigma^{\top}\right)$ \\
\hline Nannostomus unifasciatus & 22 & Cuieiras River, AM & $\left(09+130^{7}\right)$ \\
\hline
\end{tabular}




\subsection{Chromosome Preparation and C-Banding}

Mitotic chromosomes were obtained from kidney tissue using the air-drying technique according to Bertollo et al. [24]. Constitutive heterochromatin was visualized by C-banding following Sumner [25].

\subsection{Repetitive DNA Mapping with Fluorescence In Situ Hybridization (FISH)}

We mapped 5S and 18S rDNA tandem repeats generated from the genomic DNA of wolf fish Hoplias malabaricus by PCR amplification [26,27]. In the case of 5S rDNA, the resulting amplification product contained 120 base pairs (bp) of the 5S rRNA encoding region and $200 \mathrm{bp}$ of the non-transcribed spacer (NTS). The second amplified fragment encompassed a 1400-bp-long segment of the 18S rRNA gene. 5S rDNA was labeled with digoxigenin-dUTP and 18S rDNA by biotin-dUTP, respectively, both by a nick translation kit, according to the manufacturer's recommendations (Roche, Mannheim, Germany). Fluorescence in situ hybridization (FISH) was performed under high stringency conditions, essentially following Yano et al. [28]. The hybridization mixture for each slide contained $100 \mathrm{ng}$ of each probe, $50 \%$ deionized formamide, and $10 \%$ dextran sulphate $(\mathrm{pH}=7.0)$, and it was denatured at $86^{\circ} \mathrm{C}$ for $6 \mathrm{~min}$ prior to application. Chromosome preparations were denatured in $70 \%$ formamide in $2 \times \mathrm{SSC}(\mathrm{pH}=7.0)$ for $3 \mathrm{~min}$ at $70^{\circ} \mathrm{C}$. Following overnight incubation at $37^{\circ} \mathrm{C}$ in a moist chamber, post-hybridization washes were performed once in $2 \times \mathrm{SSC}\left(5 \mathrm{~min}\right.$ at $\left.42^{\circ} \mathrm{C}\right)$ and once in $1 \times \mathrm{SSC}(5 \mathrm{~min}$, Room Temperature). Prior to the probe detection, $3 \%$ non-fat dried milk (NFDM) in $2 \times$ SSC was applied on each slide ( $5 \mathrm{~min}, \mathrm{RT}$ ) to avoid the non-specific binding of antibodies. Probes were then detected using Avidin-FITC (Sigma, St. Louis, MO, USA) and Anti-Digoxigenin-Rhodamin (Roche, Basel, Switzerland). Finally, chromosomes were counterstained with 4.6-diamidino-2-phenylindole (DAPI) $(1.2 \mu \mathrm{g} / \mathrm{mL})$ and mounted in an antifade solution (Vector, Burlingame, CA, USA).

\subsection{Comparative Genomic Hybridization (CGH)}

We designed a set of experiments aimed at inter-specific genomic DNA comparison among all studied Nannostomus species. For this purpose, genomic DNAs (gDNA) from males and females of all species were isolated from liver tissue using a standard phenol/chloroform/isoamyl alcohol extraction [29]. We performed a set of separate experiments, where the $N$. beckfordi genomic probe was co-hybridized with the gDNA of one of the remaining species under study, against the chromosome background of $N$. beckfordi. The probes were generated again by nick translation reaction (Roche) as described above, with a differential labeling system employing biotin-dUTP (for N. beckfordi) and digoxigenin-dUTP (for N. eques, N. marginatus, and N. unifasciatus). Besides $500 \mathrm{ng}$ of each labeled probe, the final hybridization mixture also contained $10 \mu \mathrm{g}$ of unlabeled $\mathrm{C}_{0} \mathrm{t}-1$ DNA generated from a $N$. beckfordi female and $10 \mu \mathrm{g}$ of unlabeled $\mathrm{C}_{0} \mathrm{t}-1$ DNA from the female of the compared species, in order to outcompete the excess of shared repetitive sequences. $\mathrm{C}_{0} \mathrm{t}-1 \mathrm{DNA}$ was prepared according to Zwick et al. [30]. The probes were precipitated with 100\% ethanol and the air-dried pellets were mixed with a hybridization buffer containing 50\% formamide, $10 \%$ SDS, $10 \%$ dextran sulfate, $2 \times$ SSC, and Denhardt's buffer ( $\mathrm{pH}$ 7.0). The hybridization process took place in a moist chamber at $37^{\circ} \mathrm{C}$ for $72 \mathrm{~h}$. The hybridization procedure was performed according to Sember et al. [31]. After post-hybridization washes, done twice in 50\% formamide in $2 \times \mathrm{SSC}, \mathrm{pH} 7.0\left(44^{\circ} \mathrm{C}, 10 \mathrm{~min}\right.$ each) and three times in $1 \times$ SSC ( $44^{\circ} \mathrm{C}, 7 \mathrm{~min}$ each), the probes were detected using Anti-Digoxigenin-Rhodamin (Roche, Basel, Switzerland) and Avidin-FITC (Sigma, St. Louis, MO, USA). Chromosomes were then counterstained with DAPI in antifade solution, as described above.

\subsection{Microscopy and Image Processing}

In total, 10 to 20 metaphases per individual were analyzed to confirm the $2 n$, chromosome morphology and FISH results. Images were captured using an Olympus BX50 microscope (Olympus Corporation, Ishikawa, Japan) with CoolSNAP and the images were processed using Image-Pro Plus 4.1 software (Media Cybernetics, Silver Spring, MD, USA). Chromosomes were classified as metacentric (m), 
submetacentric (sm), subtelocentric (st), or acrocentric (a) according to their centromere positions [32]. Karyotypes were arranged according to the chromosome size within each chromosome category.

\section{Results}

\subsection{Conventional Cytogenetic Characteristics}

The examined species differed markedly both in the $2 n$ and karyotype composition (Figure 2). The karyotypes of $N$. beckfordi $(2 n=44, \mathrm{FN}=44$, where FN stands for the number of chromosome arms, i.e., fundamental number) and $N$. eques $(2 n=36, \mathrm{FN}=36)$ were formed exclusively by acrocentric chromosomes. N. marginatus displayed, however, $2 n=42$ and $\mathrm{FN}=44$, with only one (the largest) metacentric pair in an otherwise fully acrocentric set of chromosomes. In striking contrast, the karyotype of $N$. unifasciatus exhibited $2 n=22$ and $\mathrm{FN}=44$, where all chromosomes were bi-armed only (i.e., metacentric and submetacentric ones) (Figure 2).

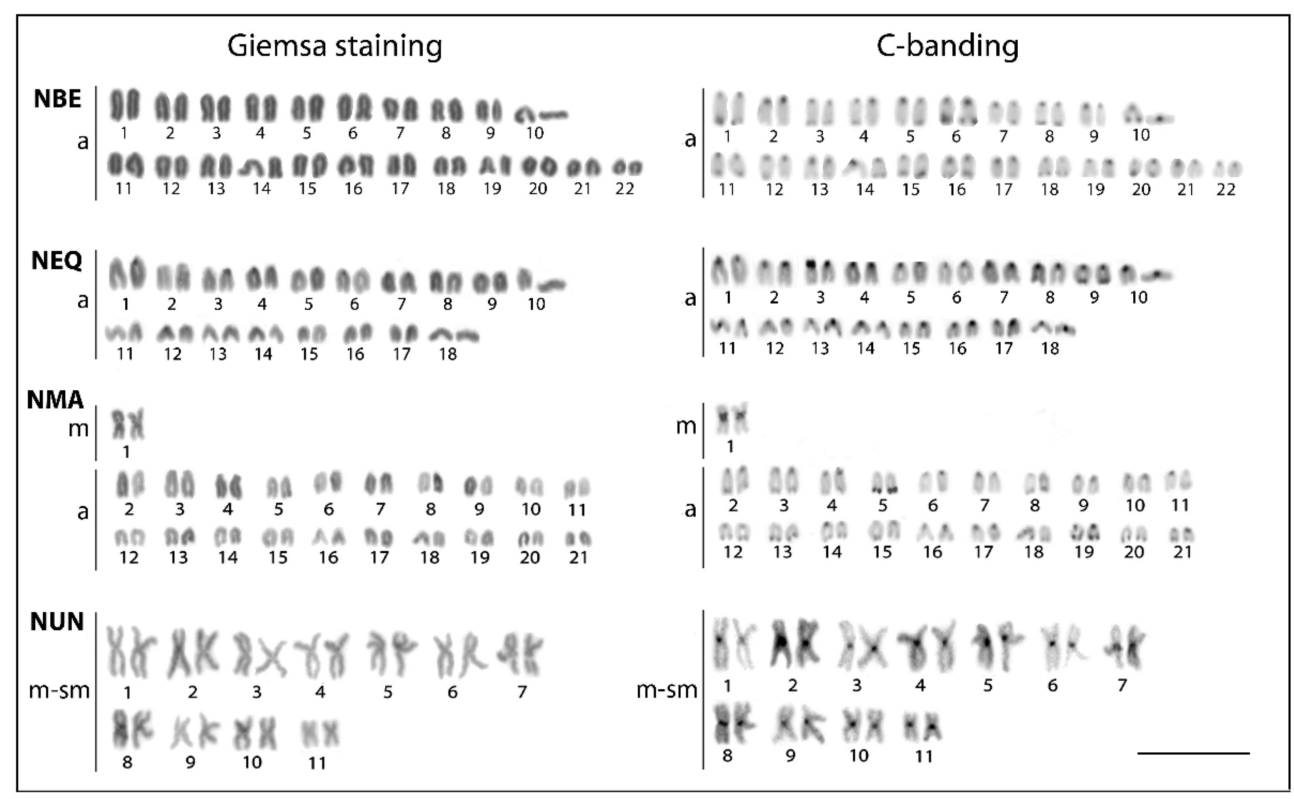

Figure 2. Karyotypes of Nannostomus species arranged after conventional cytogenetic protocols. Giemsa staining (left panel), C-banding (right panel). Abbreviations: NBE = Nannostomus beckfordi, NEQ = N . eques, $\mathrm{NMA}=\mathrm{N}$. marginatus, $\mathrm{NUN}=\mathrm{N}$. unifasciatus. Note a remarkable difference in the number, size, and morphology of chromosomes in N. unifasciatus in comparison to other studied species. Bar $=5 \mu \mathrm{m}$.

C-banding revealed that the constitutive heterochromatin is mainly confined to centromeric regions in all species. Terminal bands could be occasionally found in several (N. beckfordi) to few (N. marginatus, N. eques) chromosomes. Conspicuous heterochromatic blocks were found flanking the centromeres of all metacentric chromosomes in N. unifasciatus and the same counts also for a single metacentric pair in N. marginatus (Figure 2).

\subsection{Patterns of $5 S$ and $18 S$ rDNA Distribution as Revealed by FISH}

All karyotypes resulting from the rDNA FISH experiments are shown in Figure 3. The 5S rDNA probe revealed only one pair of signals in N. beckfordi and N. unifasciatus while the karyotypes of other species displayed two pairs with this repeat. The second pair of $5 S$ rDNA signals was placed on the short ( $p$ ) arms of the acrocentric chromosome pair No. 10 (in N. eques) and in the pericentromeric region of the acrocentric chromosome pair No. 19 (N. marginatus), respectively. Moreover, the karyotype of $N$. unifasciatus differed from those of the other species in that it had two syntenic sites in the large metacentric pair No. 2, one located in the proximal region and the second placed interstially. 


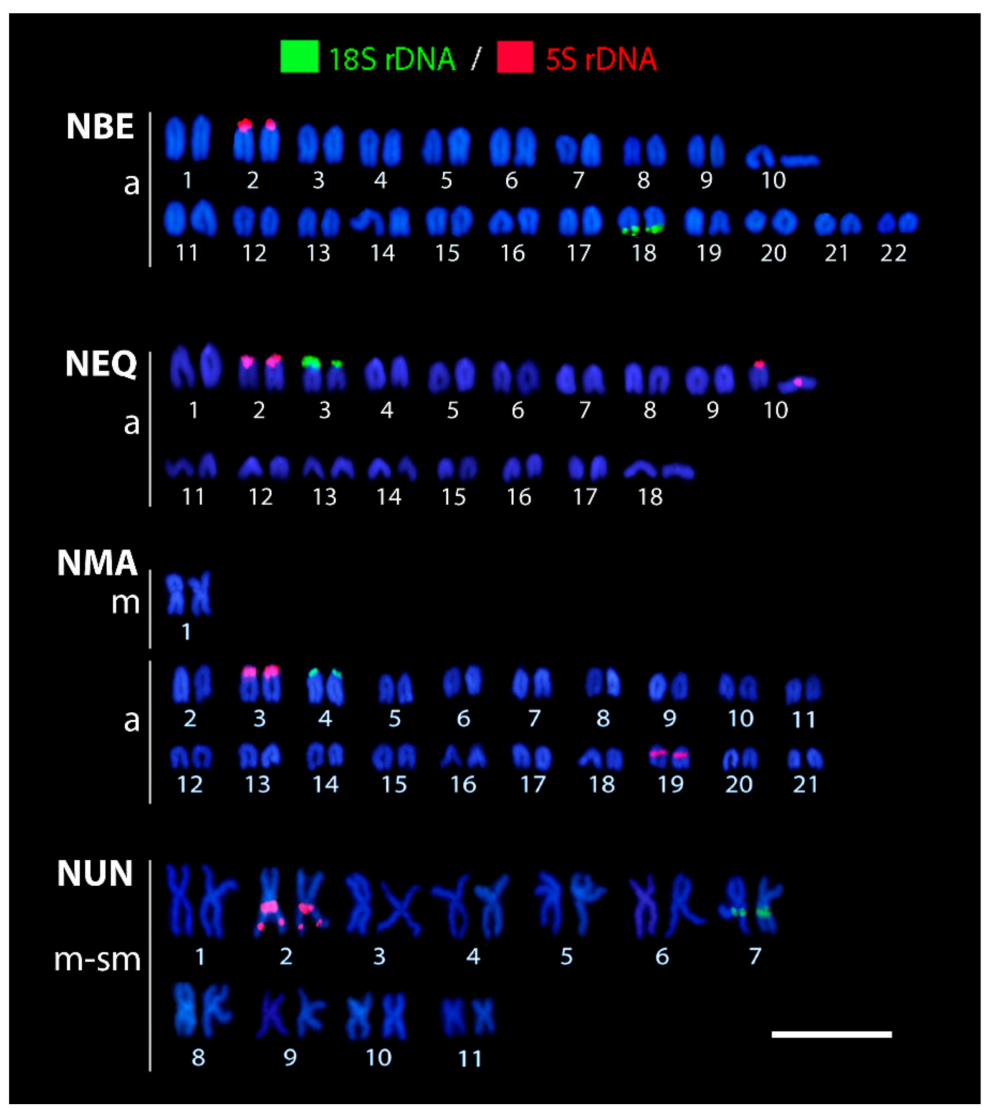

Figure 3. Karyotypes of Nannostomus species arranged after dual-color FISH with 5S and 18S rDNA probes. The FISH scheme includes $5 \mathrm{~S}$ rDNA (red signals) and $18 \mathrm{~S}$ rDNA (green signals) probes), and chromosomes were counterstained with DAPI. Abbreviations: NBE = Nannostomus beckfordi, NEQ = $N$. eques, $\mathrm{NMA}=N$. marginatus, $\mathrm{NUN}=\mathrm{N}$. unifasciatus. Note the exceptional hybridization patterns in $N$. unifasciatus (specifically, the doubled 5S rDNA sites and the position of both rDNA classes near the centromeres of large metacentric chromosomes). Bar $=5 \mu \mathrm{m}$.

The $18 \mathrm{~S}$ rDNA probe marked a single chromosomal pair in all species; however, the location of the signals differed slightly among species. While they were situated on the $p$-arms of the acrocentric pair No. 3 in N. eques and No. 4 in N. marginatus, respectively, N. beckfordi bore 18S rDNA sites on the terminal part of the long $(q)$ arms of the acrocentric pair No. 18. Finally, N. unifasciatus displayed these cistrons in the proximal region of the metacentric pair No. 7.

\subsection{Patterns of Interspecific Genome Divergence as Revealed by CGH}

Cross-species CGH analysis revealed in each separate experiment rather equal binding of both co-hybridized genomic probes to all N. beckfordi chromosomes, thus yielding composite yellow signals (i.e., a combination of green and red). This hybridization pattern indicates the shared repetitive DNA content in the respective regions. Both probes hybridized preferentially to many centromeric and telomeric regions. In some cases, the intensity of the signals was biased towards either N. beckfordi genomic probe or to the probe of the compared species, probably reflecting the differential amount of specific repetitive DNA classes in the compared genomes. In addition, the chromosomes of N. beckfordi also showed many repetitive DNA accumulations which were stained exclusively by the N. beckfordi probe (Figure 4). 


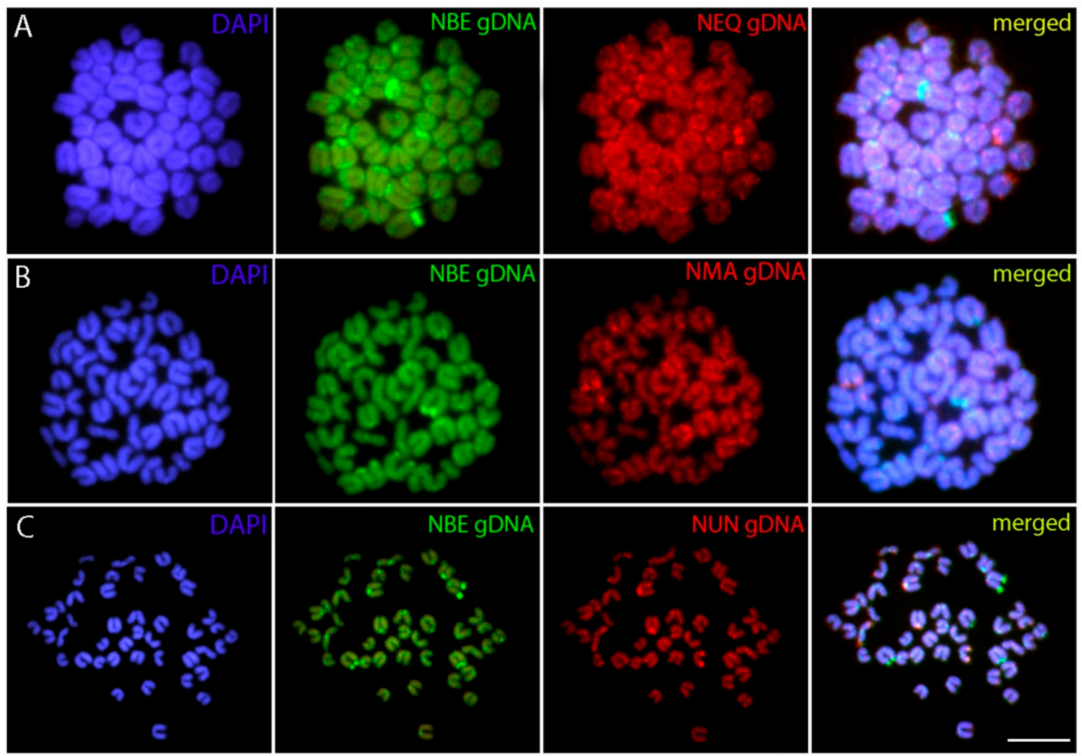

Figure 4. Mitotic chromosome spreads of Nannostomus beckfordi after interspecific CGH. Male-derived genomic DNA probe from (A) N. eques, (B) N. marginatus, and (C) N. unifasciatus mapped against male chromosomes of N. beckfordi. First column: DAPI images (blue); Second column: hybridization pattern produced by the genomic probe from one of the compared species; Third column: hybridization patterns produced by the genomic probe of N. beckfordi. Fourth column: merged images of both genomic probes and DAPI counterstaining. The common genomic regions are highlighted in yellow (i.e., a combination of the green and red hybridization probe). Bar $=5 \mu \mathrm{m}$.

\section{Discussion}

The herein studied Nannostomus species displayed a significant variability in the $2 n$ values but with a stable FN equal to 44 in all but one species ( $N$. eques; FN = 36). These patterns strongly indicated a series of Robertsonian rearrangements, for which the classification of chromosome arm numbers, i.e., NF value, was originally developed [33]. Nonetheless, because of a lack of clear landmarks to identify the individual chromosome pairs, the comparison across species is arbitrary and based on the chromosomal size and morphology only.

It is necessary to determine whether the evolutionary trajectory of karyotype change in Nannostomus is directed mainly towards centric fusions or fissions [34]. For this, the modal $2 n$ of characiform fishes and the phylogenetic relationship of Nannostomus with the nearest lebiasinid lineages may provide a first useful indication (the principle reviewed in Dobigny et al. [35]). Thus, taking into account that (1) the modal $2 n$ for characiforms very likely may be $2 n=54$ [36], (2) Lebiasina, the most basal genus of Lebiasinidae [14] is characterized by $2 n=36$ [21], and (3) the same $2 n$ is also present among Ctenoluciidae species [37], a probable sister family of Lebiasinidae [38], we can infer that the reduction of $2 n$ among the Nannostomus species was most likely achieved by a series of chromosome fusions. Specifically, according to Benzaquem et al. [15], N. unifasciatus, with $2 n=22$ and with a karyotype formed exclusively by bi-armed chromosomes, is phylogenetically closely related to $N$. beckfordi, which possesses $2 n=44$ and a karyotype formed by acrocentric chromosomes only. Therefore, considering their relationship, the chromosomal divergence between these species is clearly evidenced by their same NF and different karyotype compositions. Altogether, this suggests that centric fusions were the most probable mechanism behind the emergence of $22 \mathrm{~m}$-sm chromosomes present in N. unifasciatus.

From the cytogenetic standpoint only, certain repetitive DNA markers, including $5 S$ and $18 \mathrm{~S}$ rDNA, have been formerly found to be involved in the formation of centric fusions (e.g., [39-41]). In the case of rDNAs, this may be possibly linked with the susceptibility of these tandemly repeated clusters to double-stranded DNA breaks, perhaps resulting from (1) a frequent rRNA transcription and thus break-prone R-loop emergence, (2) intermingling of NOR (Nuclear Organizer Region)-bearing 
chromosomes in the interphase nucleus, or (3) possible association of rDNA-bearing sites during the meiotic prophase I [42-48]. With a few exceptions, the terminal position of the 18S rDNA loci on chromosomes appears to be a common feature for all Lebiasinidae genera analyzed up to now (i.e., Nannostomus, Pyrrhulina, Lebiasina, and Copeina) ([19-22], this study). Altogether with Ctenoluciidae [37], this pattern can be considered as symplesiomorphy for both families. Although $5 S$ rDNA displays a more dynamic evolution, with both terminal and interstitial signals among lebiasinids ([19-22], this study), it is noteworthy that N. unifasciatus underwent structural chromosome rearrangements involving both $18 \mathrm{~S}$ and $5 \mathrm{~S} \mathrm{rDNA}$ loci, which have led to a derived pattern of rDNA distribution in this species. It is a rather expected scenario for $N$. unifasciatus, since this species exhibits the lowest $2 n$ among Lebiasinidae fishes $(2 n=22)$ and hence it may be speculated that the proximal $18 \mathrm{~S}$ and $5 \mathrm{~S}$ rDNA sites found in N. unifasciatus might rather represent hallmarks of fusion, suggesting the probable direction of chromosome change in this genus. However, despite this observation, it is obvious that, especially in N. unifasciatus, there might not be a preferential involvement of rDNA-bearing chromosomes in the formation of centric fusion, as many other uni-armed elements have been engaged in this process, leading to entirely bi-armed karyotype. Therefore, inversely, no major role of rDNA sites in the formation of fusions can so far be hypothesized in Nannostomus. Finer-scale analysis expanded in both taxonomic breadth and the number of cytogenetic markers is needed in order to better characterize the karyotype dynamics and to track whether there were also centric fissions or other types of rearrangements occurring in parallel in Nannostomus karyotype differentiation.

As another layer of evidence supporting the significant contribution of fusions in the karyotype dynamics of Nannostomus, the large blocks of constitutive heterochromatin flanking the centromeres of rather large-sized metacentric chromosomes, as found in the karyotypes of N. marginatus and N. unifasciatus, may be potentially considered as relics of two previously independent centromeres linked together by the process of fusion. In fact, such a situation has been repeatedly observed in many teleost species (sometimes, again, accompanied by the presence of rDNA sites in the fusion points) [49-54] and it was reported also in other animal taxa, e.g., amphibians [55] or mammals [56,57]. Nonetheless, other studies show that the large pericentromeric heterochromatic blocks can also be found evenly distributed throughout the karyotype regardless of the fusion events (see, e.g., Houck et al. [57] and Sousa et al. [58]).

Despite centric fusions not being a dominant type of chromosome rearrangement in teleosts, it seems that such a mechanism might indeed predominate in some lineages [59]. Within Teleostei, similar patterns of karyotype differentiation as those unraveled in Nannostomus have also been reported for African annual killifish genera Nothobranchius [60] and Chromaphyosemion [61,62], Gobiidae [63], Nothothenoidei [64], ophichthid eels (Ophichthidae) [54], Umbridae [65,66], and, in a broader context, also in the paleopolyploid Salmonidae family, where this process is apparently linked to the re-diploidization processes [67].

Gradual fixation of chromosome fusions may be linked to various selective pressures or to genetic drift $[34,68,69]$. It is also conceivable that the degree to which centric fusions are tolerated by the species' genome might be determined by specific properties linked to chromatin functional arrangement within the interphase nucleus, such as, e.g., elevated plasticity in the organization of chromosome territories, compartments, and topologically-associating domains [70-76]. It has been shown, for instance, that properly separated chromosome territories prevent the formation of inter-chromosomal fusions [77] and that changes in the architecture of the interphase genome may lead to severe consequences in gene expression [76]. Nonetheless, a recent study shows a high tolerance to disruption of the genome topology by rearrangements in the fruit fly Drosophila melanogaster [78]. Therefore, we may theorize that some organisms may better tolerate such alterations while others may be very sensitive to them, with selection acting strongly against the formation of inter-chromosomal rearrangements. Examples of both scenarios can be found among Teleostei, where some clades maintain constant $2 n$ equal to 48 or 50 chromosomes while other lineages, including the genus Nannostomus, undergo frequent Robertsonian rearrangements [79]. It will therefore be an important aim for the future research to determine the main drivers behind such contrasting karyotype dynamics. 
The distribution of repetitive DNAs may provide important clues about the pace of genome dynamics and it may also answer several taxonomic issues [9,10,80,81]. Chromosomal mapping of rDNA clusters has repeatedly helped to unveil diverse evolutionary issues (e.g., [82,83]). Particularly in fishes, it provided valuable clues about the incidence of cryptic, morphologically indistinguishable sibling species $[5,6,8,10,84]$, polyploidization and interspecific hybridization events [85,86], a geographical gradient of genomic and morphological change [87], patterns of sex chromosome differentiation [80,88-90], and the correlation of genome dynamics in response to environmental cues [91,92]. Among the Nannostomus species investigated here, chromosomal mapping revealed somewhat uniform patterns of distribution for both rDNA classes, with one to few sites of accumulation, as found in most fishes [93,94], as well as in some other lebiasinids [21,22] investigated to date. While some of these sites may appear to be orthologous among the species under study, the frequently high dynamics of these repetitive DNA classes do not allow us to make certain conclusions without additional data (for an exemplary study, see Milhomem et al. [95]). Nonetheless, in addition to the fact that some rDNA sites were clearly involved in Robertsonian fusions (as mentioned above), it may be inferred that like some other related lebiasinids [19], Nannostomus species do not show a substantial level of intrachromosomal dynamics that could be detected by the markers selected by us. This inference is further supported by the low to moderate amount of constitutive heterochromatin revealed by C-banding. Another supporting evidence for this assumption came from the CGH experiments. Despite CGH and related methods represent rather "rough" molecular tools, they may show patterns of the genomic divergence between species, as they rely on the presence of genome-specific repetitive DNA classes. As repetitive DNA usually evolves rapidly in diverging genomes, such an approach may yield specific patterns of hybridization depending on the compared species, which (within a certain evolutionary timeframe) correlate with the degree of their divergence [31,96-98]. In the present study, rather minor interspecific differences in the composition of repetitive DNA among the compared Nannostomus species were shown. In summary, we propose that the karyotype differentiation in Nannostomus, at least in the species under study, was driven mainly by major structural rearrangements and the repetitive DNA content has not yet diverged significantly among the investigated genomes.

Chromosome rearrangements may not always be directly linked to speciation [68], but they may often provide an effective mechanism for post-zygotic reproductive isolation (in the case of fusions, e.g., $[57,99,100])$. By altering gene expression or by joining previously unlinked genetic material together, for instance, they might facilitate the emergence of evolutionarily advanced (e.g., locally adapted) sub-populations of a given species, thus contributing to diversification $[69,101]$. In addition, they might also be linked to the emergence of novel sex chromosome systems, such as that recently found in the lebiasinid genus Pyrrhulina [20]. Lastly, although additional detailed cytogenetic studies are still needed on a wider taxonomic scale, the present data reinforced the assumption that chromosomal fusions were important drivers of the karyotype evolution in the Neotropical family Lebiasinidae and, especially, in the pencil fishes of the genus Nannostomus.

Author Contributions: Conceptualization, A.S., P.R.; Formal analysis, A.S., E.A.d.O., P.F.V., C.F.Y., M.d.B.C., M.M.F.M., R.L.R.d.M. and E.F.; Funding acquisition, A.S., L.A.C.B. and M.d.B.C.; Investigation, A.S., E.A.d.O., L.A.C.B., N.L.d.F., P.F.V., C.F.Y., T.H., M.M.F.M. and E.F.; Methodology, A.S., E.A.d.O., N.L.d.F., P.F.V., C.F.Y., M.d.B.C., T.H., M.M.F.M. and R.L.R.d.M.; Project administration, M.d.B.C.; Supervision, A.S., L.A.C.B. and M.d.B.C.; Validation, A.S., P.R., E.A.d.O., N.L.d.F., C.F.Y., T.H., M.M.F.M., R.L.R.d.M., P.R. and E.F.; Visualization, L.A.C.B., P.F.V., C.F.Y., M.d.B.C. and T.H.; Writing-original draft, A.S., P.R. and N.L.d.F.; Writing-review and editing, E.A.d.O., L.A.C.B., P.F.V., C.F.Y., M.d.B.C., T.H., M.M.F.M., R.L.R.d.M., P.R. and E.F. All authors have read and agreed to the published version of the manuscript.

Funding: M.B.C. was supported by Conselho Nacional de Desenvolvimento Científico e Tecnológico (CNPq) (Proc. nos 401962/2016-4 and 302449/2018-3) and CAPES/Alexander von Humboldt (Proc. No. 88881.136128/2017-01). L.A.C.B. was supported by Conselho Nacional de Desenvolvimento Científico e Tecnológico (CNPq) (Proc. nos 401575/2016-0 and 306896/2014-1), and the Fundação de Amparo à Pesquisa do Estado de São Paulo (FAPESP) (Proc. No. 2018/24235-0). M.M.F.M. was supported by the Fundação de Amparo à Pesquisa do Estado de São Paulo (FAPESP) (Proc. No. 2017/09321-5; 2018/114115). This study was financed in part by the 
Coordenação de Aperfeiçoamento de Pessoal de Nível Superior, Brasil (CAPES), Finance Code 001.A.S. was supported by Conselho Nacional de Desenvolvimento Científico e Tecnológico - CNPq (152105/2016-6), PPLZ: L200451751 and with the institutional support RVO: 67985904. P.R. was supported by the project EXCELLENCE CZ.02.1.01/0.0/0.0/15_003/0000460 OP RDE and by RVO: 67985904.

Conflicts of Interest: The authors declare no conflict of interest.

\section{References}

1. Albert, J.S.; Reis, R.E. Historical Biogeography of Neotropical Freshwater Fishes, 1st ed.; University of California Press: Berkeley, CA, USA, 2011.

2. Nelson, J.S.; Grande, T.C.; Wilson, M.V.H. Fishes of the World, 5th ed.; John Wiley \& Sons: Hoboken, NJ, USA, 2016.

3. Reis, R.E.; Albert, J.S.; Di Dario, F.; Mincarone, M.M.; Petry, P.; Rocha, L.A. Fish biodiversity and conservation in South America. J. Fish Biol. 2016, 89, 12-47. [CrossRef] [PubMed]

4. Pereira, L.H.G.; Hanner, R.; Foresti, F.; Oliveira, C. Can DNA barcoding accurately discriminate megadiverse Neotropical freshwater fish fauna? BMC Genet. 2013, 14, 20. [CrossRef] [PubMed]

5. Ferreira, M.; Kavalco, K.F.; de Almeida-Toledo, L.F.; Garcia, C. Cryptic diversity between two Imparfinis species (Siluriformes, Heptapteridae) by cytogenetic analysis and DNA barcoding. Zebrafish 2014, 11, 306-317. [CrossRef] [PubMed]

6. Ferreira, M.; Garcia, C.; Matoso, D.A.; de Jesus, I.S.; Cioffi, M.B.; Bertollo, L.A.C.; Zuanon, J.; Feldberg, E. The Bunocephalus coracoideus species complex (Siluriformes, Aspredinidae). Signs of a speciation process through chromosomal, genetic and ecological diversity. Front. Genet. 2017, 8, 1-12. [CrossRef]

7. Ramirez, J.L.; Birindelli, J.L.; Carvalho, D.C.; Affonso, P.R.A.M.; Venere, P.C.; Ortega, H.; Carrillo-Avila, M.; Rodríguez-Pulido, J.A.; Galetti, P.M., Jr. Revealing hidden diversity of the underestimated neotropical ichthyofauna: DNA barcoding in the recently described genus Megaleporinus (Characiformes: Anostomidae). Front. Genet. 2017, 8, 1-11. [CrossRef]

8. Prizon, A.C.; Bruschi, D.P.; Borin-Carvalho, L.A.; Cius, A.; Barbosa, L.M.; Ruiz, H.B.; Zawadzki, C.H.; Fenocchio, A.S.; Portela-Castro, A.L.B. Hidden diversity in the populations of the armored catfish Ancistrus Kner, 1854 (Loricariidae, Hypostominae) from the Paraná River Basin revealed by molecular and cytogenetic data. Front. Genet. 2017, 8, 185. [CrossRef]

9. Cioffi, M.B.; Moreira-Filho, O.; Ráb, P.; Sember, A.; Molina, W.F.; Bertollo, L.A.C. Conventional cytogenetic approaches-Useful and indispensable tools in discovering fish biodiversity. Curr. Genet. Med. Rep. 2018, 6, 176-186. [CrossRef]

10. Cioffi, M.B.; Molina, W.F.; Artoni, R.F.; Bertollo, L.A.C. Chromosomes as tools for discovering biodiversity-The case of Erythrinidae fish family. In Recent Trends in Cytogenetic Studies—Methodologies Applications, 1st ed.; Tirunilai, P., Ed.; INTECH: London, UK, 2012; Volume 1, pp. 125-146.

11. Cioffi, M.B.; Yano, C.F.; Sember, A.; Bertollo, L.A.C. Chromosomal evolution in lower vertebrates: Sex chromosomes in Neotropical fishes. Genes 2017, 8, 258. [CrossRef]

12. Bertollo, L.A.C. Chromosome evolution in the neotropical Erythrinidae fish family: An overview. In Fish Cytogenetics, 1st ed.; Pisano, E., Ed.; CRC Press: Boca Raton, FL, USA, 2007; pp. 195-211.

13. Catalog of Fishes: Genera, Species, References. Available online: http://researcharchive.calacademy.org/ research/ichthyology/catalog/fishcatmain.asp (accessed on 1 October 2019).

14. Netto-Ferreira, A.L. Revisão taxonômica e relações interespecíficas de Lebiasininae (Ostariophysi: Characiformes: Lebiasinidae). Ph.D. Thesis, Universidade de São Paulo, São Paulo, Brazil, 2010.

15. Benzaquem, D.C.; Oliveira, C.; da Silva Batista, J.; Zuanon, J.; Porto, J.I.R. DNA barcoding in pencilfishes (Lebiasinidae: Nannostomus) reveals cryptic diversity across the brazilian Amazon. PLoS ONE 2015, 10, e0112217. [CrossRef]

16. Scheel, J.J. Fish Chromosomes and Their Evolution; Danmarks Akvarium: Charlottenlund, Denmark, 1973.

17. Oliveira, C.; Andreata, A.; Almeida-Toledo, L.F.; Toledo Filho, S.A. Karyotype and nucleolus organizer regions of Pyrrhulina cf. australis (Pisces, Characiformes, Lebiasinidae). Rev. Bras. Genet. 1991, 14, 685-690.

18. Arai, R. Fish Karyotypes: A Check List, 1st ed.; Springer: Tokyo, Japan, 2011.

19. Moraes, R.L.R.; Bertollo, L.A.C.; Marinho, M.M.F.; Yano, C.F.; Hatanaka, T.; Barby, F.F.; Troy, W.P.; Cioffi, M.B. Evolutionary relationships and cytotaxonomy considerations in the genus Pyrrhulina (Characiformes, Lebiasinidae). Zebrafish 2017, 14, 536-546. [CrossRef] [PubMed] 
20. Moraes, R.L.; Sember, A.; Bertollo, L.A.C.; de Oliveira, E.A.; Ráb, P.; Hatanaka, T.; Marinho, M.M.F.; Liehr, T.; Al-Rikabi, A.B.H.; Feldberg, E.; et al. Comparative cytogenetics and neo-Y formation in small-sized fish species of the genus Pyrrhulina (Characiformes, Lebiasinidae). Front. Genet. 2019, 10, 1-13. [CrossRef] [PubMed]

21. Sassi, F.M.C.; de Oliveira, E.A.; Bertollo, L.A.C.; Nirchio, M.; Hatanaka, T.; Marinho, M.M.F.; Moreira-Filho, O.; Aroutiounian, R.; Liehr, T.; Al-Rikabi, A.B.H.; et al. Chromosomal evolution and evolutionary relationships of Lebiasina species (Characiformes, Lebiasinidae). Int. J. Mol. Sci. 2019, 20, 2944. [CrossRef] [PubMed]

22. Toma, G.A.; Moraes, R.L.R.; Sassi, F.M.C.; Bertollo, L.A.C.; de Oliveira, E.A.; Ráb, P.; Sember, A.; Liehr, T.; Hatanaka, T.; Viana, P.F.; et al. Cytogenetics of the small-sized fish, Copeina guttata (Characiformes, Lebiasinidae): Novel insights into the karyotype differentiation of the family. PLoS ONE 2019, 14, e0226746. [CrossRef] [PubMed]

23. Arefjev, V.A. Karyotypic diversity of characid families (Pisces, Characidae). Caryologia 1990, 43, $291-304$. [CrossRef]

24. Bertollo, L.A.C.; Cioffi, M.B.; Moreira-Filho, O. Direct chromosome preparation from Freshwater teleost fishes. In Fish Cytogenetic Techniques (Ray-Fin Fishes and Chondrichthyans), 1st ed.; Ozouf-Costaz, C., Pisano, E., Foresti, F., Toledo, L.F.A., Eds.; CRC Press: Boca Raton, FL, USA, 2015; Volume 1, pp. 21-26.

25. Sumner, A.T. A simple technique for demonstrating centromeric heterochromatin. Exp. Cell Res. 1972, 75, 304-306. [CrossRef]

26. Martins, C.; Ferreira, I.A.; Oliveira, C.; Foresti, F.; Galetti, P.M., Jr. A tandemly repetitive centromeric DNA sequence of the fish Hoplias malabaricus (Characiformes: Erythrinidae) is derived from $5 \mathrm{~S}$ rDNA. Genetica 2006, 127, 133-141. [CrossRef]

27. Cioffi, M.B.; Martins, C.; Centofante, L.; Jacobina, U.; Bertollo, L.A.C. Chromosomal variability among allopatric populations of Erythrinidae fish Hoplias malabaricus: Mapping of three classes of repetitive DNAs. Cytogenet. Genome Res. 2009, 125, 132-141. [CrossRef]

28. Yano, C.F.; Bertollo, L.A.C.; Cioffi, M.B. Fish-FISH: Molecular cytogenetics in fish species. In Fluorescence in Situ Hybridization (FISH)—Application Guide, 2nd ed.; Liehr, T., Ed.; Springer: Berlin, Germany, 2017; pp. 429-444.

29. Sambrook, J.; Russell, D.W. Molecular Cloning: A Laboratory Manual, 3rd ed.; Cold Spring Harbor Laboratory Press: New York, NY, USA, 2001.

30. Zwick, M.S.; Hanson, R.E.; Islam-Faridi, M.N.; Stelly, D.M.; Wing, R.A.; Price, H.J.; McKnight, T.D. A rapid procedure for the isolation of C0t-1 DNA from plants. Genome 1997, 40, 138-142. [CrossRef]

31. Sember, A.; Bertollo, L.A.C.; Ráb, P.; Yano, C.F.; Hatanaka, T.; de Oliveira, E.A.; Cioffi, M.B. Sex chromosome evolution and genomic divergence in the fish Hoplias malabaricus (Characiformes, Erythrinidae). Front. Genet. 2018, 9, 1-12. [CrossRef]

32. Levan, A.; Fredga, K.; Sandberg, A.A. Nomenclature for centromeric position on chromosomes. Hereditas 1964, 52, 201-220. [CrossRef]

33. Matthey, R. L' evolution de la formule chromosomiale chez les vertebrees. Experientia 1945, 1, 78-86. [CrossRef]

34. King, M. Species Evolution: The Role of Chromosome Change, 1st ed.; Cambridge University Press: Cambridge, UK, 1993.

35. Dobigny, G.; Ducroz, J.-F.; Robinson, T.J.; Volobouev, V. Cytogenetics and cladistics. Syst. Biol. 2004, 53, 470-484. [CrossRef] [PubMed]

36. Oliveira, C.; Almeida-Toledo, L.F.; Foresti, F. Karyotypic evolution in Neotropical fishes. In Fish Cytogenetics, 1st ed.; Pisano, E., Ozouf-Costaz, C., Foresti, F., Kapoor, B.G., Eds.; Science Publishers: Enfield, CT, USA, 2007; pp. 111-164.

37. Souza e Sousa, J.F.; Viana, P.F.; Bertollo, L.A.C.; Cioffi, M.B.; Feldberg, E. Evolutionary relationships among Boulengerella species (Ctenoluciidae, Characiformes): Genomic organization of repetitive DNAs and highly conserved karyotypes. Cytogenet. Genome Res. 2017, 152, 194-203. [CrossRef]

38. Betancur-R, R.; Arcila, D.; Vari, R.P.; Hughes, L.C.; Oliveira, C.; Sabaj, M.H.; Ortí, G. Phylogenomic incongruence, hypothesis testing, and taxonomic sampling: The monophyly of characiform fishes. Evolution 2019, 73, 329-345. [CrossRef]

39. De Barros, A.V.; Wolski, M.A.V.; Nogaroto, V.; Almeida, M.C.; Moreira-Filho, O.; Vicari, M.R. Fragile sites, dysfunctional telomere and chromosome fusions: What is $5 \mathrm{~S}$ rDNA role? Gene 2017, 608, 20-27. [CrossRef]

40. Cavalcante, M.G.; Eduardo, C.; Carvalho, M.; Nagamachi, Y.; Pieczarka, J.C.; Vicari, M.R.; Noronha, R.C.R. Physical mapping of repetitive DNA suggests 2n reduction in Amazon turtles Podocnemis (Testudines: Podocnemididae). PLoS ONE 2018, 13, e0197536. [CrossRef] 
41. Glugoski, L.; Giuliano-Caetano, L.; Moreira-Filho, O.; Vicari, M.R.; Nogaroto, V. Co-located $h A T$ transposable element and 5S rDNA in an interstitial telomeric sequence suggest the formation of Robertsonian fusion in armored catfish. Gene 2018, 650, 49-54. [CrossRef]

42. Schweizer, D.; Loidl, J. A model for heterochromatin dispersion and the evolution of C-band patterns. In Chromosomes Today, 1st ed.; Stahl, A., Luciani, J.M., Vagner-Capodano, A.M., Eds.; Springer: Paris, France, 1987; Volume 9, pp. 61-74. [CrossRef]

43. Ráb, P.; Crossman, E.J.; Reed, K.M.; Rábová, M. Chromosomal characteristics of ribosomal DNA in two extant species of North American mudminows Umbra pygmaea and U. limi (Euteleostei: Umbridae). Cytogenet. Genome Res. 2002, 98, 194-198. [CrossRef]

44. Cazaux, B.; Catalan, J.; Veyrunes, F.; Douzery, E.J.; Britton-Davidian, J. Are ribosomal DNA clusters rearrangement hotspots? A case study in the genus Mus (Rodentia, Muridae). BMC Evol. Biol. 2011, 11, 124. [CrossRef]

45. Santos-Pereira, J.M.; Aguilera, A. R loops: New modulators of genome dynamics and function. Nat. Rev. Genet. 2015, 16, 583-597. [CrossRef] [PubMed]

46. Sawyer, I.A.; Dundr, M. Chromatin loops and causality loops: The influence of RNA upon spatial nuclear architecture. Chromosoma 2017, 126, 541-557. [CrossRef]

47. Blokhina, Y.P.; Nguyen, A.D.; Draper, B.W.; Burgess, S.M. The telomere bouquet is a hub where meiotic double-strand breaks, synapsis, and stable homolog juxtaposition are coordinated in the zebrafish, Danio rerio. PLoS Genet. 2019, 15, e1007730. [CrossRef] [PubMed]

48. Potapova, T.A.; Gerton, J.L. Ribosomal DNA and the nucleolus in the context of genome organization. Chromosome Res. 2019, 27, 109-127. [CrossRef] [PubMed]

49. Giles, V.; Thode, G.; Alvarez, M.C. A new Robertsonian fusion in the multiple chromosome polymorphism of a mediterranean population of Gobius paganellus (Gobiidae, Perciformes). Heredity 1985, 55, 255-260. [CrossRef]

50. Molina, W.F.; Galetti, P.M., Jr. Robertsonian rearrangements in the reef fish Chromis (Perciformes, Pomacentridae) involving chromosomes bearing 5S rRNA genes. Genet. Mol. Biol. 2002, 25, 373-377. [CrossRef]

51. Rosa, K.O.; Ziemniczak, K.; de Barros, A.V.; Nogaroto, V.; Almeida, M.C.; Cestari, M.M.; Artoni, R.F.; Vicari, M.R. Numeric and structural chromosome polymorphism in Rineloricaria lima (Siluriformes: Loricariidae): Fusion points carrying $5 \mathrm{~S}$ rDNA or telomere sequence vestiges. Rev. Fish Biol. Fish. 2012, 22, 739-749. [CrossRef]

52. Sember, A.; Bohlen, J.; Šlechtová, V.; Altmanová, M.; Symonová, R.; Ráb, P. Karyotype differentiation in 19 species of river loach fishes (Nemacheilidae, Teleostei): Extensive variability associated with rDNA and heterochromatin distribution and its phylogenetic and ecological interpretation. BMC Evol. Biol. 2015, 15, 251. [CrossRef]

53. Getlekha, N.; Molina, W.F.; Cioffi, M.B.; Yano, C.F.; Maneechot, N.; Bertollo, L.A.C.; Supiwong, W.; Tanomtong, A. Repetitive DNAs highlight the role of chromosomal fusions in the karyotype evolution of Dascyllus species (Pomacentridae, Perciformes). Genetica 2016, 144, 203-211. [CrossRef]

54. Salvadori, S.; Deiana, A.M.; Deidda, F.; Lobina, C.; Mulas, A.; Coluccia, E. XX/XY sex chromosome system and chromosome markers in the snake eel Ophisurus serpens (Anguilliformes: Ophichtidae). Mar. Biol. Res. 2018, 14, 158-164. [CrossRef]

55. Schmid, M.; Steinlein, C.; Bogart, J.P.; Feichtinger, W.; León, P.; La Marca, E.; Díaz, L.M.; Sanz, A.; Chen, S.H.; Hedges, S.B. The chromosomes of terraran frogs: Insights into vertebrate cytogenetics. Cytogenet. Genome Res. 2016, 130-131, 1-568. [CrossRef]

56. Da Costa, M.J.R.; do Amaral, P.J.S.; Pieczarka, J.C.; Sampaio, M.I.; Rossi, R.V.; Mendes-Oliveira, A.C.; Noronha, R.C.R.; Nagamachi, C.Y. Cryptic species in Proechimys goeldii (Rodentia, Echimyidae)? A case of molecular and chromosomal differentiation in allopatric populations. Cytogenet. Genome Res. 2016, 148, 199-210. [CrossRef] [PubMed]

57. Houck, M.L.; Teri, L.; Lear, T.L.; Charter, S.J. Animal cytogenetics. In The AGT Cytogenetics Laboratory Manual, 4th ed.; Arsham, M.S., Barch, M.J., Lawce, H.J., Eds.; John Wiley \& Sons: Hoboken, NJ, USA, 2017; pp. 1055-1102.

58. Sousa, R.P.C.; Oliveira-Filho, A.B.; Vallinoto, M.; Cioffi, M.B.; Molina, W.F.; de Oliveira, E.H.; Silva-Oliveira, G.C. Cytogenetics description in Batrachoides surinamensis, (Batrachoididae: Batrachoidiformes): What does the estuary have to say? Estuar. Coast. Shelf Sci. 2018, 213, 253-259. [CrossRef]

59. Molina, W.F.; Martinez, P.A.; Bertollo, L.A.C.; Bidau, C.J. Evidence for meiotic drive as an explanation for karyotype changes in fishes. Mar. Genom. 2014, 15, 29-34. [CrossRef]

60. Krysanov, E.; Demidova, T. Extensive karyotype variability of African fish genus Nothobranchius (Cyprinodontiformes). Comp. Cytogenet. 2018, 12, 387-402. [CrossRef] 
61. Völker, M.; Sonnenberg, R.; Ráb, P.; Kullmann, H. Karyotype differentiation in Chromaphyosemion killifishes (Cyprinodontiformes, Nothobranchiidae) II: Cytogenetic and mitochondrial DNA analyses demonstrate karyotype differentiation and its evolutionary direction in C. riggenbachi. Cytogenet. Genome Res. 2006, 115, 70-83. [CrossRef]

62. Völker, M.; Ráb, P.; Kullmann, H. Karyotype differentiation in Chromaphyosemion killifishes (Cyprinodontiformes, Nothobranchiidae): Patterns, mechanisms, and evolutionary implications. Biol. J. Linn. Soc. 2008, 94, 143-153. [CrossRef]

63. Ene, A.-C. Chromosomal polymorphism in the goby Neogobius eurycephalus (Perciformes: Gobiidae). Mar. Biol. 2002, 142, 583-588. [CrossRef]

64. Amores, A.; Wilson, C.A.; Allard, C.A.H.; Detrich, H.W.; Postlethwait, J.H. Cold fusion: Massive karyotype evolution in the Antarctic bullhead notothen Notothenia coriiceps. G3 (Bethesda) 2017, 7, 2195-2207. [CrossRef]

65. Crossman, E.J.; Ráb, P. Chromosome-banding study of the Alaska blackfish, Dallia pectoralis (Euteleostei: Esocae) with implications for karyotype evolution and relationships of esocoid fishes. Can. J. Zool. 1996, 74, 147-156. [CrossRef]

66. Crossman, E.J.; Ráb, P. Chromosomal NOR phenotype and C-banded karyotype of Olympic mudminnow, Novumbra hubbsi (Euteleostei: Umbridae). Copeia 2001, 3, 860-865. [CrossRef]

67. Phillips, R.; Ráb, P. Chromosome evolution in the Salmonidae (Pisces): An update. Biol. Rev. Camb. Philos. Soc. 2001, 76, 1-25. [CrossRef] [PubMed]

68. Brown, J.D.; O’Neill, R.J. Chromosomes, conflict, and epigenetics: Chromosomal speciation revisited. Annu. Rev. Genom. Hum. Genet. 2010, 11, 291-316. [CrossRef] [PubMed]

69. Guerrero, R.F.; Kirkpatrick, M. Local adaptation and the evolution of chromosome fusions. Evolution 2014, 68, 2747-2756. [CrossRef]

70. Lanctôt, C.; Cheutin, T.; Cremer, M.; Cavalli, G.; Cremer, T. Dynamic genome architecture in the nuclear space: Regulation of gene expression in three dimensions. Nat. Rev. Genet. 2007, 8, 104-115. [CrossRef]

71. Meaburn, K.J.; Misteli, T.; Soutoglou, E. Spatial genome organization in the formation of chromosomal translocations. Semin. Cancer Biol. 2007, 17, 80-90. [CrossRef]

72. Meaburn, K.J.; Misteli, T. Cell biology: Chromosome territories. Nature 2007, 445, 379-781. [CrossRef]

73. Cremer, T.; Cremer, M. Chromosome territories. Cold Spring Harb. Perspect. Biol. 2010, 2, 1-23. [CrossRef]

74. Roukos, V.; Misteli, T. The biogenesis of chromosome translocations. Nat. Cell Biol. 2014, 16, 293-300. [CrossRef]

75. Fraser, J.; Williamson, I.; Bickmore, W.A.; Dostie, J. An overview of genome organization and how we got there: From FISH to Hi-C. Microbiol. Mol. Biol. Rev. 2015, 79, 347-372. [CrossRef]

76. Razin, S.V.; Gavrilov, A.A.; Vassetzky, Y.S.; Ulianov, S.V. Topologically-associating domains: Gene warehouses adapted to serve transcriptional regulation. Transcription 2016, 7, 84-90. [CrossRef] [PubMed]

77. Rosin, L.F.; Crocker, O.; Isenhart, R.L.; Nguyen, S.C.; Xu, Z.; Joyce, E.F. Chromosome territory formation attenuates the translocation potential of cells. eLife 2019, 8, e49553. [CrossRef] [PubMed]

78. Ghavi-Helm, Y.; Jankowski, A.; Meiers, S.; Viales, R.R.; Korbel, J.O.; Furlong, E.E.M. Highly rearranged chromosomes reveal uncoupling between genome topology and gene expression. Nat. Genet. 2019, 51, 1272-1282. [CrossRef] [PubMed]

79. Mank, J.E.; Avise, J.C. Phylogenetic conservation of chromosome numbers in Actinopterygiian fishes. Genetica 2006, 127, 321-327. [CrossRef] [PubMed]

80. Cioffi, M.B.; Bertollo, L.A.C. Chromosomal distribution and evolution of repetitive DNAs in fish. Genome Dyn. 2012, 7, 197-221. [CrossRef]

81. García-Souto, D.; Qarkaxhija, V.; Pasantes, J.J. Resolving the taxonomic status of Chamelea gallina and C. striatula (Veneridae, Bivalvia): A combined molecular cytogenetic and phylogenetic approach. Biomed. Res. Int. 2017, 2017, 7638790. [CrossRef]

82. Weeks, A.R.; Marec, F.; Breeuwer, J.A.J. A mite species that consists entirely of haploid females. Science 2001, 292, 2479-2482. [CrossRef]

83. Lukhtanov, V.A.; Dincă, V.; Friberg, M.; Šíchová, J.; Olofsson, M.; Vila, R.; Marec, F.; Wiklund, C. Versatility of multivalent orientation, inverted meiosis, and rescued fitness in holocentric chromosomal hybrids. PNAS 2018, 115, E9610-E9619. [CrossRef]

84. Do Nascimento, V.D.; Coelho, K.A.; Nogaroto, V.; Almeida, R.B.; Ziemniczak, K.; Centofante, L.; Pavanelli, C.S.; Torres, R.A.; Moreira-Filho, O.; Vicari, M.R. Do multiple karyomorphs and population genetics of freshwater darter characines (Apareiodon affinis) indicate chromosomal speciation? Zool. Anz. 2018, 272, 93-103. [CrossRef] 
85. Zhu, H.P.; Ma, D.M.; Gui, J.F. Triploid origin of the gibel carp as revealed by 5 S rDNA localization and chromosome painting. Chromosome Res. 2006, 14, 767-776. [CrossRef]

86. Zhang, C.; Ye, L.; Chen, Y.; Xiao, J.; Wu, Y.; Tao, M.; Xiao, Y.; Liu, S. The chromosomal constitution of fish hybrid lineage revealed by 5 S rDNA FISH. BMC Genet. 2015, 16, 140. [CrossRef] [PubMed]

87. Soto, M.Á.; Castro, J.P.; Walker, L.I.; Malabarba, L.R.; Santos, M.H.; Almeida, M.C.; Moreira-Filho, O.; Artoni, R.F. Evolution of trans-Andean endemic fishes of the genus Cheirodon (Teleostei: Characidae) are associated with chromosomal rearrangements. Rev. Chil. Hist. Nat. 2018, 91, 8. [CrossRef]

88. Yano, C.F.; Bertollo, L.A.C.; Ezaz, T.; Trifonov, V.; Sember, A.; Liehr, T.; Cioffi, M.B. Highly conserved Z and molecularly diverged $\mathrm{W}$ chromosomes in the fish genus Triportheus (Characiformes, Triportheidae). Heredity 2017, 118, 276-283. [CrossRef] [PubMed]

89. De Oliveira, E.A.; Sember, A.; Bertollo, L.A.C.; Yano, C.F.; Ezaz, T.; Moreira-Filho, O.; Hatanaka, T.; Trifonov, V.; Liehr, T.; Al-Rikabi, A.B.H.; et al. Tracking the evolutionary pathway of sex chromosomes among fishes: Characterizing the unique $\mathrm{XX} / \mathrm{XY}_{1} \mathrm{Y}_{2}$ system in Hoplias malabaricus (Teleostei, Characiformes). Chromosoma 2018, 127, 115-128. [CrossRef] [PubMed]

90. Xu, D.; Sember, A.; Zhu, Q.; de Oliveira, E.A.; Liehr, T.; Al-Rikabi, A.B.H.; Xiao, Z.; Song, H.; Cioffi, M.B. Deciphering the origin and evolution of the $\mathrm{X}_{1} \mathrm{X}_{2} \mathrm{Y}$ system in two closely-related Oplegnathus species (Oplegnathidae and Centrarchiformes). J. Mol. Sci. 2019, 20, 3571. [CrossRef] [PubMed]

91. Symonová, R.; Majtánová, Z.; Sember, A.; Staaks, G.B.; Bohlen, J.; Freyhof, J.; Rábová, M.; Ráb, P. Genome differentiation in a species pair of coregonine fishes: An extremely rapid speciation driven by stress-activated retrotransposons mediating extensive ribosomal DNA multiplications. BMC Evol. Biol. 2013, 13, 42. [CrossRef]

92. Da Silva, A.F.; Feldberg, E.; Carvalho, N.D.M.; Rangel, S.M.H.; Schneider, C.H.; Carvalho-Zilse, G.A.; da Silva, V.F.; Gross, M.C. Effects of environmental pollution on the rDNAomics of Amazonian fish. Environ. Pollut. 2019, 252, 180-187. [CrossRef]

93. Gornung, E. Twenty years of physical mapping of major ribosomal RNA genes across the teleosts: A review of research. Cytogenet. Genome Res. 2013, 141, 90-102. [CrossRef]

94. Sochorová, J.; Garcia, S.; Gálvez, F.; Symonová, R.; Kovař́ík, A. Evolutionary trends in animal ribosomal DNA loci: Introduction to a new online database. Chromosoma 2018, 127, 141-150. [CrossRef]

95. Milhomem, S.S.R.; Scacchetti, P.C.; Pieczarka, J.C.; Ferguson-Smith, M.A.; Pansonato-Alves, J.C.; O'Brien, P.C.M.; Foresti, F.; Nagamachi, C.Y. Are NORs always located on homeologous chromosomes? A FISH investigation with rDNA and whole chromosome probes in Gymnotus fishes (Gymnotiformes). PLoS ONE 2013, 8, e55608. [CrossRef]

96. Lim, K.Y.; Kovař́k, A.; Matyášek, R.; Chase, M.W.; Clarkson, J.J.; Grandbastien, M.A.; Leitch, A.R. Sequence of events leading to near-complete genome turnover in allopolyploid Nicotiana within five million years. New Phytol. 2007, 175, 756-763. [CrossRef] [PubMed]

97. Majka, J.; Majka, M.; Kwiatek, M.; Wiśniewska, H. Similarities and differences in the nuclear genome organization within Pooideae species revealed by comparative genomic in situ hybridization (GISH). J. Appl. Genet. 2017, 58, 151-161. [CrossRef] [PubMed]

98. Barby, F.F.; Bertollo, L.A.C.; de Oliveira, E.A.; Yano, C.F.; Hatanaka, T.; Ráb, P.; Sember, A.; Ezaz, T.; Artoni, R.F.; Liehr, T.; et al. Emerging patterns of genome organization in Notopteridae species (Teleostei, Osteoglossiformes) as revealed by Zoo-FISH and Comparative Genomic Hybridization (CGH). Sci. Rep. 2019, 9, 1112. [CrossRef] [PubMed]

99. Kandul, N.P.; Lukhtanov, V.A.; Pierce, N.E. Karyotypic diversity and speciation in Agrodiaetus butterflies. Evolution 2007, 61, 546-559. [CrossRef] [PubMed]

100. Luo, J.; Sun, X.; Cormack, B.P.; Boeke, J.D. Karyotype engineering by chromosome fusion leads to reproductive isolation in yeast. Nature 2018, 560, 392-396. [CrossRef]

101. Ortiz-Barrientos, D.; Engelstädter, J.; Rieseberg, L.H. Recombination rate evolution and the origin of species. Trends Ecol. Evol. 2016, 31, 226-236. [CrossRef]

(C) 2020 by the authors. Licensee MDPI, Basel, Switzerland. This article is an open access article distributed under the terms and conditions of the Creative Commons Attribution (CC BY) license (http://creativecommons.org/licenses/by/4.0/). 